Original scientific paper

\title{
BIOGAS ENERGY - A CHANCE FOR AGRICULTURE AND RURAL DEVELOPMENT? INSIGHT FROM THE POST-COMMUNIST CENTRAL EUROPE
}

\author{
Justyna CHODKOWSKA-MISZCZUK ${ }^{1 \mathrm{a}}$, Marián KULLA ${ }^{\mathrm{b}}$, Ladislav \\ NOVOTNÝ
}

\begin{abstract}
aDepartment of Urban and Regional Development Studies, Faculty of Earth Sciences and Spatial Management, Nicolaus Copernicus University, Toruń, Poland; Lwowska 1, 87-100 Toruń, Poland, phone: +48566112561, e-mail: jchodkow@umk.pl

bInstitute of geography, Faculty of Science, Pavol Jozef Šafárik University, Košice, Slovakia; Jesenná 5, 04001 Košice, Slovakia, phone: +421 55234 2352, e-mail: marian.kulla@upjs.sk

'Institute of geography, Faculty of Science, Pavol Jozef Šafárik University, Košice, Slovakia; Jesenná 5, 04001 Košice, Slovakia, phone: +421 55234 2353, e-mail: ladislav.novotny@upjs.sk
\end{abstract}

Cite this article: Chodkowska-Miszczuk, J., Kulla, M., Novotný, L. (2019). Biogas energy - a chance for agriculture and rural development? Insight from the post-communist Central Europe. Deturope, 11(2), 30-53.

\begin{abstract}
Biogas production has recently expanded across the post-communist Central European countries. This paper addresses the role of biogas plants based on agricultural resources (agri-food waste and agricultural crops) as a new factor of rural development in Poland and Slovakia, and so it contributes to the comprehensive research on effects of agricultural biogas energy production. The analysis is based on a set of quantitative and qualitative methods, and the results are thoroughly illustrated by two case studies of agricultural biogas plants representing specific features and circumstances of biogas plants in both countries. The results reveal mutual conditionality between operating plants and agricultural structures. The study also provides insight into the impact of agricultural biogas plants operation to the rural development including stabilization of agricultural production thanks to improvement of its multifunctionality and points to the differences between two kinds of biogas plants regarding their ownership and national legal specifics.
\end{abstract}

Keywords: multifunctional agriculture, biogas energy, rural development, Poland, Slovakia.

\section{INTRODUCTION}

Number of Agricultural Biogas Plants (ABPs) operating in post-communist Central European countries (CECs) has increased considerably over the last decade. This reflects efforts of European Union (EU) to diversify its energy sources in favor of the renewable energy sources (RES). Corresponding legal framework and financial support models were adopted by individual EU countries but rapid development of agricultural biogas energy production led some of them to adopt legal changes to curb it (Chodkowska-Miszczuk, Kulla and Novotný,

\footnotetext{
${ }^{1}$ Corresponding author: jchodkow@umk.pl
} 
2017, Chodkowska-Miszczuk, Biegańska, Środa-Murawska, Grzelak-Kostulska, \& Rogatka, 2016).

Agriculture in majority of CECs has been coping with fundamental conversion since the post-communist transformation. Many farms bankrupted and many still have to fight for survival. The role of agriculture in national economies decreased, but it is still significant economic activity and remains decisive particularly in rural areas. In order to utilize economic potential of rural areas effectively, projects aimed at the functional diversification of agriculture were developed which is in line with the trends and proposals from Western countries (cf. Wilson, 2007, Renting et al. 2009). To develop multifunctional agriculture, many projects focus on utilization of agricultural products to generate renewable energy in ABPs. Beside contribution to agriculture and rural economies development, a positive environmental impact of ABPs operation is emphasized (cf. Auer et al. 2017).

An ABP is a project with significant impact on the spatial, social and economic conditions of a given area (Ostrowska, 2012). The spatial and economic aspects of biogas production stimulated recent research in the post-communist CECs (Budzianowski, 2012, Curkowski, 2012, Rusňák, Pepich and Muráňová, 2013, Martinát, Dvořák, Klusáček et al., 2013, Martinát, Dvořák, Frantál et al., 2013, Chodkowska-Miszczuk and Szymańska, 2013, ChodkowskaMiszczuk, 2014, Szymańska and Lewandowska, 2015, Van der Horst et al., 2018) but only marginal attention has been paid to the role of ABPs as a stimulus for transformation of agriculture and rural economies. Moreover, due to specific features of the post-communist CECs (Kats, 1991, Buzar, 2007) it is not possible to apply a knowledge from Western Europe fully to this region. This, together with rapidly increased number of ABPs, persisting problems of conversion of agriculture and transformation of rural areas, underlines a need for further research in these countries.

Therefore, the aim of this paper is to assess the role of ABPs as a new factor of agriculture transformation and rural development in the post-communist CECs. In order to identify regularities and differences under various conditions, the research is spatially focused on Poland and Slovakia as the countries representing common features of modern historical development of the post-communist CECs.

The study employs a set of quantitative and qualitative methods complemented by in-depth research in two ABPs chosen to confront indicated results with experiences from two entities with different business links to agriculture, the acquisition of substrates, and utilization of final products. 


\section{THEORETICAL BACKGROUND}

Global energy consumption is growing rapidly and the society cannot rely fully on the fossil fuels anymore. Renewable energy sources (RES) are perceived as favorable option to provide greater diversification of energy sources (cf. deLlano-Paz et al., 2015), and make their spatial distribution more even. This also contributes to sustainable development and can be beneficial for local economy, communities as well as the power sector (Wolfe, 2008, Ackermann, Andersson and Söder, 2011, Chodkowska-Miszczuk, 2014).

In relation to the future of agriculture and rural development, the concept of the multifunctional agriculture has become frequently addressed by scholars and even policy makers since the early 2000s. As a concept, it was first used at the Earth Summit in Rio de Janeiro in 1992 (cf. Jean-Vasile 2013). In general, multifunctional agriculture refers to the agricultural activities beyond traditional function of agriculture - producing food, fiber and feed for animal production. Such activities and functions may include renewable natural resources management, landscape and biodiversity conservation and contribution to the social and economic viability of rural areas (Renting et al. 2009). Rural areas and agriculture are integrally connected, and relation between them is bidirectional: change within one causes the transformations within the other. Hence, an effective and long-term development of rural areas requires the diversification of agriculture and its multifunctional development. New economic activities based on agricultural resources contribute to the creation of new/additional sources of income not only for farmers, but also for all inhabitants of rural areas (Van Ploeg et al., 2000). Némethová (2010) emphasizes multifunctional agriculture as a chance to overcome problematic post-socialist transformation of agriculture in CECs by the example of agricultural region in southwestern Slovakia. Thus, energy production from agricultural biogas is worth examining also as a phenomenon contributing to multifunctionality of agriculture.

ABPs operate usually in rural areas and produce energy (electricity and heat) based on agricultural biogas produced by anaerobic digestion from agricultural energy crops and/or agrifood production waste. Hence, agricultural biogas is a RES, which utilizes resources available in rural areas, and so production of agricultural biogas energy supports decentralized energy production as well as development of agriculture (Chodkowska-Miszczuk and Szymańska, 2013, Martinát, Dvořák, Klusáček et al., 2013, Martinát, Dvořák, Frantál et al., 2013, Wirth et al., 2013, Yang and Chen, 2014). Among all RES installations, energy production by ABPs is the most predictable, as it is not influenced by fluctuations of natural conditions as much as wind or hydro plants (Bluemling, Mol and Tu, 2013).

Besides positive effects, some scholars emphasize also negative aspects of ABPs operation (Schulz and Eder, 2004, Gaduš and Giertl, 2010, Auer et al. 2017). Among the positives are obtaining clean and renewable energy, processing the organic residues, contribution to the 
reduction of the methane gas emissions resulting from livestock farming and also to the reduction of the overall cradle-to-gate emissions of agricultural products by replacing synthetic inorganic fertilizer, support of economic development and employment, increase of the competitiveness of agricultural sector. The negative view on the ABPs includes visual harm of locality's character, worsening the local population's quality of life (by smell, dirt), pushing down the real estate prices, discouraging tourists from visiting the area, ethical issues related to non-nutrition agriculture as well as negative impacts of possible too extensive maizemonoculture cultivation areas (Lunnan, 1997, Converse, 2007, Nonhebel, 2007). As a solution, some scholars (Sims et al., 2006, Boehmel, Lewandowski and Claupein, 2008, Bożym et al., 2015) propose to limit the structure of substrates to agricultural and food wastes, or in case of energy crops cultivated specially for biogas production to focus on the crops with the highest energy efficiency in order to reduce the spatial requirements for cultivation of these crops.

The economies of the post-communist CECs have long been experiencing domination of one energy source, high energy intensity of national economies, centralization of the national energy markets, and energy dependence from Russia (Buzar, 2007), what largely persists even nowadays. Another structural economic feature is agriculture formed under the influence of the communist regime. During this period, private farms were confiscated (almost all in Slovakia and part in Poland) and large-scale state owned farms (mainly agricultural cooperatives) established, which retained until the early 1990s.

Because of centrally planned economy, including agriculture, Poland and Slovakia are similar when considering the agricultural production effects, but they are extremely different when considering forms of the agricultural land ownership. In Slovakia, large previously stateowned and later privatized agricultural estates dominate, while there is a mix of large agricultural estates and relatively small private farms in Poland (Bański, 2008). Consequently, ABPs are established as an integral part of the large farming enterprise (typical for Slovakia) or/and as a separate entity which operation is based on cooperation with local stakeholders, including small farmers (typical for Poland).

Energy production in ABPs is regulated by national and international legislation on RES which have determining impact on development of energy from agricultural biogas production at national levels (cf. Auer et al., 2017, Chodkowska-Miszczuk, Kulla and Novotný, 2017). The Directive of the European Parliament and the Council no. 2009/28 /WE (Directive 2009/28/EC) cover the EU energy policies aiming to regulate a proportion of energy produced from RES in each member country. It determines the mandatory national goal for each EU country in order to achieve desired proportion of energy from RES in the final consumption in the EU until 2020. These goals are 15\% for Poland and 14\% for Slovakia. 
The onset of agricultural biogas plants in the EU dates back to the mid-1980s. First biogas plants, including micro-scale installations (up to $100 \mathrm{~kW}$ ), were established in Germany, Denmark and Austria (Fischer and Krieg, 2001). These countries are still among the leaders in agricultural biogas energy production (cf. Chodkowska-Miszczuk, Kulla and Novotný, 2017). Because Germany is traditional and currently the largest agricultural biogas energy producer, we chose it as a reference case for comparisons with development in Poland and Slovakia.

In Germany, the number of plants was increasing by more than thousand a year in the period 2009-2011. However, beside increase in the number of ABPs, their structure changed in favor of large installations what led to increase of average installed capacity from less than 0.085 MW in 2001 (Weiland, 2003) to almost 0.4 MW in 2010 (Budzianowski and Chasiak, 2011). It also led to increase in consumption of energy crops as substrates for biogas production at the expense of agricultural waste (mainly liquid manure). The cultivation of energy crops reached up one fifth of the arable land in Germany. Therefore, the biogas energy production contributed to development of multifunctional agriculture but also became perceived controversial. During the 1990s, the biogas energy was rather very welcomed agricultural by-product, but the utilization of crop acreage exclusively for energy generation started to compete with land used for food production in the 2000s (cf. Auer et al. 2017). Subsequently, the changes in the Renewable Energy Act EEG 2012 that promoted smaller installation based on agricultural waste led to dramatic slowdown in the development of German biogas energy market (Torrijos, 2016, Auer et al. 2017).

The beginning of energy production from agricultural biogas in CECs dates back two decades later. The first ABP in Slovakia launched operation in 2005 (in Hurbanovo southwestern Slovakia), but considerable development of agricultural biogas energy production started as late as the Law on the promotion of RES (Act No. 309/2009 Coll.) and National Action Plan for RES (National Action Plan for RES, 2010) were adopted in 2009 and 2010 respectively and provided rich feed in tariffs to producers. It was at the same time as the rapid growth took place in Germany. However, business uncertainty given by the policy on determining the feed in tariffs for energy from RES may be a major obstacle in further development of ABPs (Chodkowska-Miszczuk, Kulla and Novotný, 2017). High tariffs from the early stage of the support system have later decreased significantly, what led to a slowdown in the growth of the agricultural biogas energy production, and even to decommissioning of some ABPs (tab. 1).

In Poland, the first ABP started operation also in 2005 (in Pawłówko, northern Poland, Pomorskie region). As in the other CECs, energy policies have transformed over the years. The Act on RES was adopted in 2015 (Act No. 478/2015 Coll.) which includes change of support for energy production from RES to the new one including auction system. This makes energy 
producers uncertain about revenues from energy sales and the return on investments (Chodkowska-Miszczuk, Kulla and Novotný, 2017). The development by the end of observation indicates that after years of rapid growth (2010-2016), new energy policies led to slowdown in the growth of ABP number.

Table 1 Development of agricultural biogas plants numbers in Poland and Slovakia in 20052017

\begin{tabular}{|c|c|c|c|c|c|c|c|c|c|c|c|c|c|c|}
\hline indi & year & 005 & 2006 & 2007 & 2008 & 2009 & 2010 & 2011 & 2012 & 2013 & 2014 & 2015 & 2016 & 2017 \\
\hline \multirow{2}{*}{ number of ABPs } & & 1 & 1 & 1 & 3 & 7 & 8 & 16 & 28 & 42 & 58 & 78 & 94 & 96 \\
\hline & Slov & 3 & 5 & 5 & 5 & 6 & 16 & 30 & 43 & 66 & 76 & 76 & 75 & 74 \\
\hline \multirow{2}{*}{$\begin{array}{l}\text { installed capacity } \\
\text { (MW) }\end{array}$} & $\mathrm{Pc}$ & N/A & $\mathrm{N} / \mathrm{A}$ & $\mathrm{N} / \mathrm{A}$ & $\mathrm{N} / \mathrm{A}$ & $\mathrm{N} / \mathrm{A}$ & N/A & 12 & 29 & 46 & 65 & 82 & 99 & 102 \\
\hline & Slovakia & N/A & $\mathrm{N} / \mathrm{A}$ & $\mathrm{N} / \mathrm{A}$ & 2 & 4 & 9 & 19 & 41 & 65 & 78 & 91 & 93 & 91 \\
\hline \multirow{2}{*}{$\begin{array}{l}\text { gross electricity } \\
\text { generation }(\mathrm{GWh})\end{array}$} & $\mathrm{P}$ & N/A & $\mathrm{N} / \mathrm{A}$ & $\mathrm{N} / \mathrm{A}$ & N/A & $\mathrm{N} / \mathrm{A}$ & N/A & 73 & 142 & 228 & 355 & 429 & 524 & 608 \\
\hline & Slovakia & N/A & $\mathrm{N} / \mathrm{A}$ & N/A & 15 & 22 & 32 & 113 & 190 & 313 & 479 & 541 & 576 & 594 \\
\hline
\end{tabular}

Source: Curkowski (2012), RONI (2015, 2016, 2017), NCAS (2018), SOSR (2008-2017)

Unlike Germany, Slovakia, Poland and other post-socialist CECs (cf. Van der Horst et al., 2018) do not have experience with small installations. After the adoption of the relevant legislation in these countries, relatively large ABPs launched operation (cf. Chodkowska-Miszczuk, Kulla and Novotný, 2017) what can act as an unprecedented stimulus to changes in agriculture.

\section{DATA AND METHODS}

The research is methodologically based on a multi-stage procedure using both quantitative and qualitative methods. During the first phase, work centered on the desk research and comparative studies. It involved review and evaluation of official documents including EU and national legal frameworks, and analysis of the availability of reliable and comparable data on the agriculture and the energy sector, particularly energy production based on agricultural input substrates in Poland and Slovakia.

Statistical data on agriculture and biogas sector were acquired from the following authorities: The Agricultural Market Agency in Poland (AMA), National Centre for Agriculture Support (NCAS) in Poland, Energy Regulatory Office in Poland (ERO), the Local Data Bank from the Central Statistical Office in Poland (LDB CSO), the official European Funds Portal (EFP), Statistical Office of the Slovak Republic (SOSR), Regulatory Office for Network Industries in Slovakia (RONI), and Eurostat.

The selection and harmonization of data was followed by a statistical evaluation of the number and spatial distribution of ABPs development in chronological relations to legislative changes, the structure of agriculture, and changes in the production volume of the most 
important agricultural substrates of both plant and livestock nature (maize for silage or pig breeding). In order to identify existing relations between the analyzed variables, the correlation coefficient was used (in accordance with the principle of $5 \%$ probability of error, the significance level is $\mathrm{p}<0.05)$. Choropleth and diagram maps were generated for the spatial assessment and visual interpretation of the results.

The case study method was employed in the following phase of research to face results indicated by statistical analysis with experiences from chosen ABPs and local communities, and to obtain more thorough understanding of the studied processes, relations and their dynamics (cf. Miles et al., 1994). As certain differences in the average farm size, prevailing ownership of biogas stations, and the resulting dominant relations between biogas stations and agricultural enterprises were identified between Poland and Slovakia, the case studies were selected to reflect these features as much as possible. The case studies research consisted of semi-structured face-to-face interviews with the managers of both ABPs and other stakeholders, representatives of local authorities, and local leaders. A total of 11 interviews (five in Slovakia and six in Poland) were conducted with assumption that the respondents represent the different spheres of social and economic life. Each interview took between one and two hours and interviewees are anonymized on purpose. At the respondent's consent, interviews were recorded and transcribed later. For objectification of results, the interviews were made in 2015 first and then repeated in 2018 again. Despite the four-year gap, information obtained by interviews are consistent. There were no significant changes recorded in respondents' views and opinions. Both ABPs chosen for in-depth research are featured by a high level of innovation. Biogas plant in Buczek, Poland (Fig. 1) provides perspective of an ABP operating as a separate business entity, so the energy production is dependent on supplies by external contractors. Biogas plant in Rozhanovce, Slovakia operates within a large agricultural enterprise, which provides the supply of substrates and utilization of by-products. The interviews were focused mainly on the period and circumstances of launching the ABP operation, supply and structure of substrates, the spatial extent of territory from which the substrates originate, the ways of use of produced energy (electricity and heat) and digestate, contacts with local authorities, local people, local surroundings, and the impact to structural changes in agriculture and perception of multifunctional agriculture.

The final stage of the analysis was a survey conducted among local communities from the both municipalities where the analyzed ABPs are located. The aim of this survey was to achieve the inhabitants' opinion on the importance of biogas plants in the rural development. The survey consisted of sets of closed-ended questions (a form of a matrix). Open-ended questions were also added to the questionnaire, but their number was purposefully limited. Due to the purpose of this study, several issues addressed in the survey were selected for the analysis, i.e., 
knowledge of ABPs, interaction between ABPs and local entities, and perception of biogas plants. The survey was carried out between September 2017 and May 2018, in Poland and Slovakia (Tab. 2).

Table 2 Socio-demographic characteristics of respondents

\begin{tabular}{cccccccccccc}
\hline \multicolumn{3}{c}{ Gender } & \multicolumn{3}{c}{ Age (years) } & \multicolumn{3}{c}{ Educational attainment } \\
\hline \multirow{3}{*}{ Poland } & $\mathrm{F}$ & $\mathrm{M}$ & $18-24$ & $25-34$ & $35-44$ & $45-64$ & $65 \geq$ & Primary & Vocational & Secondary & Tertiary \\
\cline { 2 - 12 } Slovakia & $61 \%$ & $39 \%$ & $5 \%$ & $17 \%$ & $18 \%$ & $56 \%$ & $5 \%$ & $5 \%$ & $20 \%$ & $35 \%$ & $40 \%$ \\
\hline
\end{tabular}

Source: own study, $\mathrm{N}=150$

\section{RESULTS AND DISCUSSION}

\section{Size structure of farms and focus of agricultural production in relation with spatial distribution of agricultural biogas energy production}

Poland and Slovakia are similar when considering the agricultural production effects but extremely different in forms of the agricultural land ownership structure. In Poland, small forms, particularly family farms prevail, while in Slovakia large forms dominate, based mainly on previously state owned and later privatized agricultural cooperatives. The average farm size in Slovakia is 77.5 ha what makes it the third largest among 28 EU countries. In Poland it is 9.6 ha what ranks it among the smallest (LDB CSO, 2015). This arises from different socialist policies related to the ownership structure of agricultural land in both countries (Bański, 2008). Based on data from Eurostat (2008-2017), greater total installed capacity of ABPs in Poland is recorded in the regions (NUTS 2) with considerable share of larger farms with an area of $10-$ 15 ha $(\mathrm{r}=0.56, \mathrm{p}<0.05)$, and over $15 \mathrm{ha}(\mathrm{r}=0.67, \mathrm{p}<0.05)$. The positive correlation indicates that the ABPs' operators prefer small number of large contractors to a large number of small contractors (i.e. local farmers). This assertion is also confirmed by one of the farmers from Buczek who emphasizes that the main contractor of the Buczek ABP plant is the large farm, which receives almost $75 \%$ of the produced organic fertilizer.

Based on the interviews with managers of ABPs it is possible to summarize that suitable location with adequate accessibility of substrates is among the key factors determining a successful ABP operation. The most important sources of substrates for agricultural biogas production in Poland take the form of organic waste from animal production and agri-food processing, including raw materials from pig husbandry. In Poland, these kinds of agricultural activities are characteristic primarily for the northern, western and central regions of the country where large-area farms are located, established primarily on the premises of the former State 
Agricultural Farms. The largest numbers of ABPs in Poland are located in these regions (Fig. 1). On the other hand, utilization of livestock farming waste for energy purposes is insignificant in Slovakia (Martinát et al., 2013a).

Figure 1 Spatial distribution of ABPs and their output in Poland and in Slovakia in 2017; Own compilation based on data from NCAS (2018) and RONI (2017)

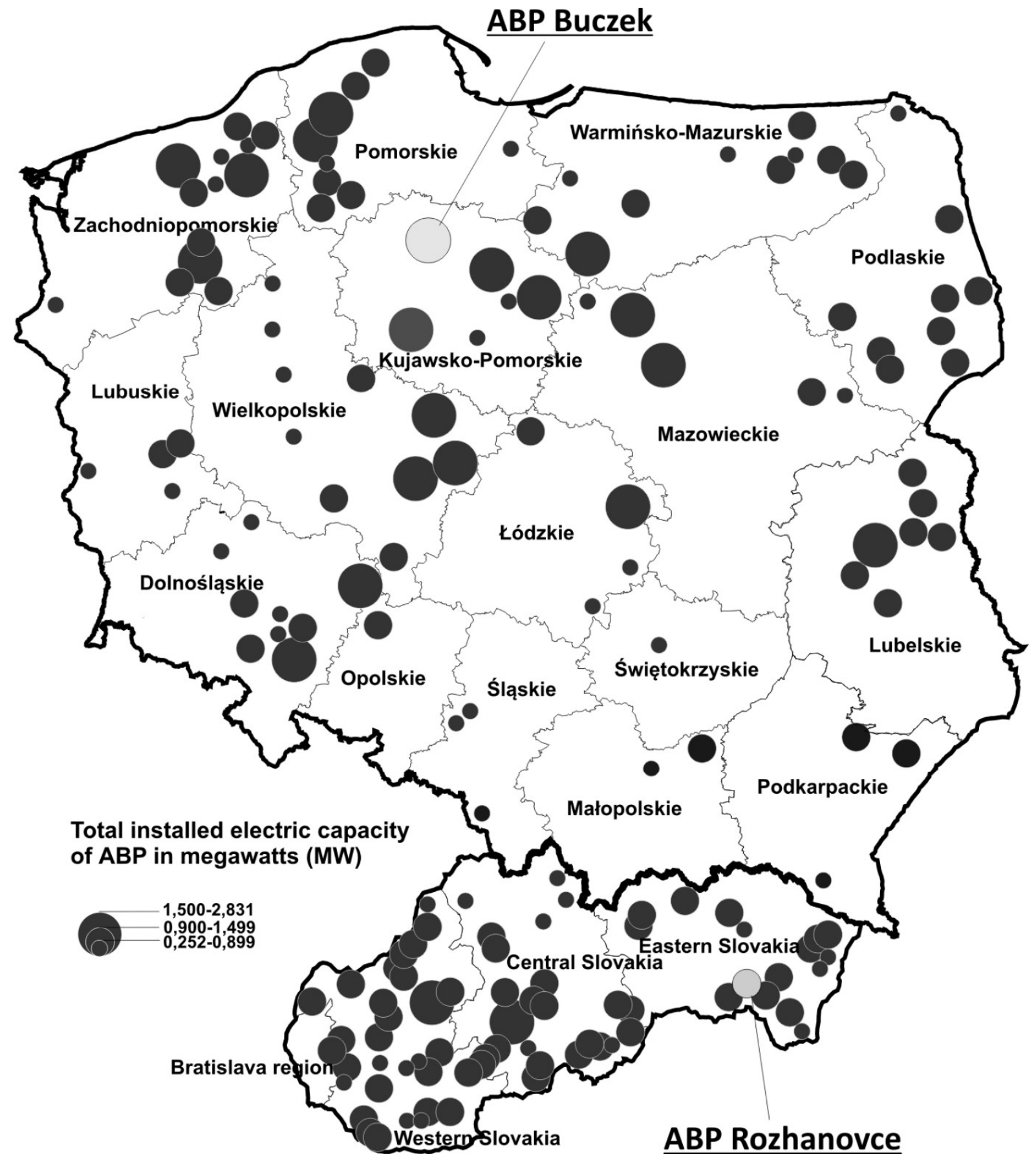


Besides the waste from agricultural production, energy crops are another important source of biogas. Results of analysis by Martinát et al. (2013a) showed the maize for silage is the most important substrate for agricultural biogas energy production in Slovakia.

Analysis of data from SOSR (2008-2017) revealed the most significant increase of the spatial extent of maize for silage cultivation since 2008 in the districts located in Western Slovakia and southern part of Central Slovakia, where majority of ABPs in the country is located (Fig. 1). This indicates certain spatial correlation between areas with increased maize production (fig. 3) and localities where the ABPs are operating. However, since higher statistical units (NUTS 2) in Slovakia do not reflect natural conditions and include areas with significantly different character of agriculture (i.e., pastoralism in the mountains, large farms in lowlands), it is not possible to express such development statistically at the level of these units. In Poland, maize accounts only for $12.4 \%$ (2017) of all substrates for biogas production. Over the last few years, there has been a few percent decrease in the share of maize, in favor of the share of waste from the agri-food industry. In 2008-2017, the area of green maize cultivation increased approximately one and half times, and as the linear regression equation indicates, this trend tends to continue (Fig. 2) despite recent decrease in the proportion of maize as a substrate for biogas production. Generally, greater increase in green maize area in Poland was recorded in the regions characterized by a higher share of large farms with an area of $10-15$ ha $(\mathrm{r}=0.64$, $\mathrm{p}<0.05)$.

The remaining almost $87 \%$ (2017) of substrates in Poland constitutes the waste from agrifood production. The highest proportion belongs to liquid manure ( $24 \%$ of all substrates from waste from agri-food production).

Before the maize for silage became utilized as an energy crop for ABPs in both countries, it was predominantly cultivated as a feed for pig husbandry. However, pig husbandry has undergone considerable recession (Fig. 4) what led to the continuous decrease in the demand for maize. This can explain why the acreage of maize for silage stabilized and even decreased by the end of period of observation (Fig. 2) which is characterized by recession of both the ABPs development (Tab. 1) and pig husbandry (Fig. 4). Without ABPs development, the acreage of maize for silage could decrease over whole period of observation in Slovakia. 
Figure 2 Changes in the area of maize for silage in Poland and Slovakia, 2008=100

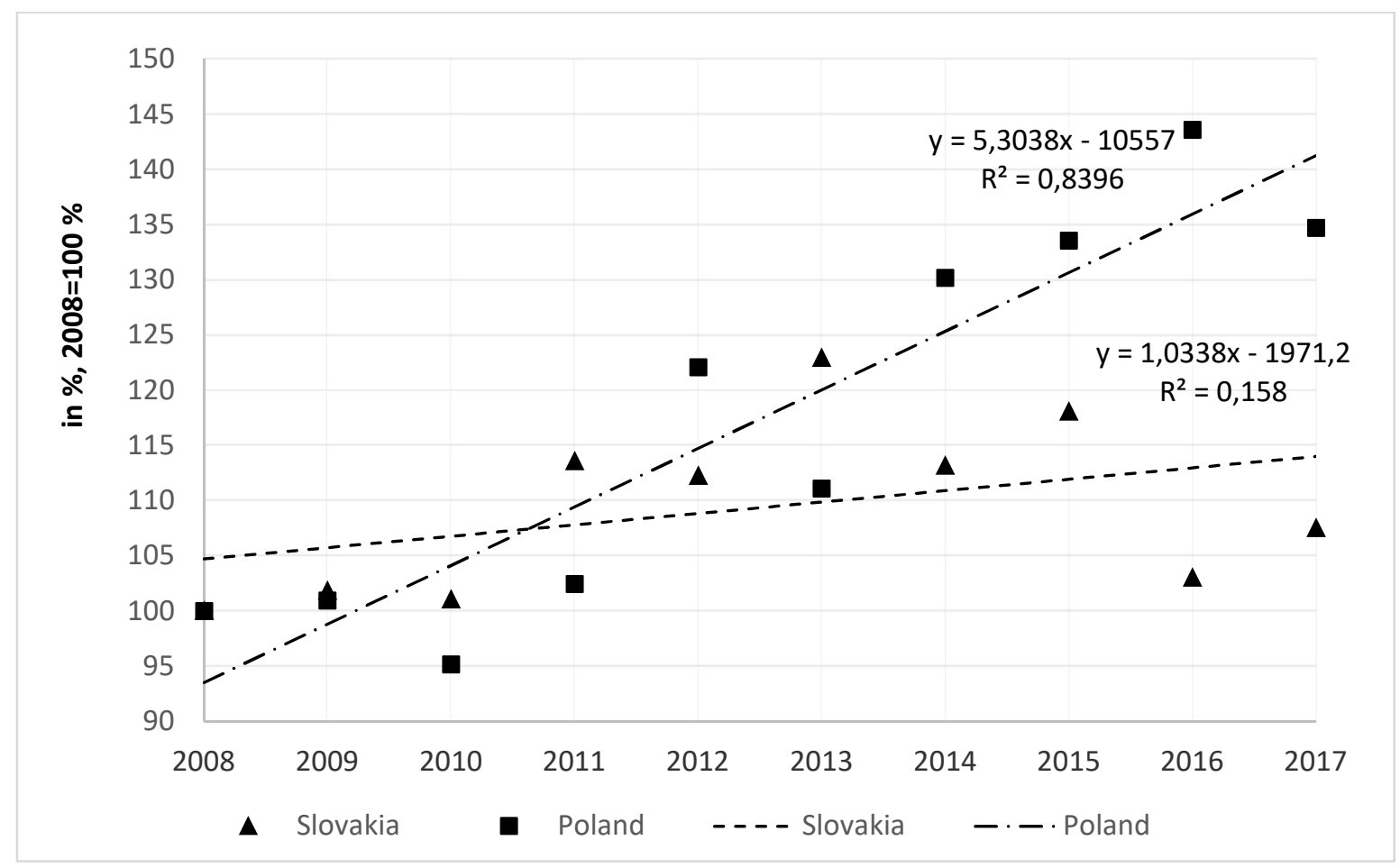

Source: (LDB CSO, 2015, Eurostat, 2018, SOSR, 2008-2017)

In Slovakia, the maize silage constitutes about $80 \%$ of all substrates for generation of biogas (Martinát et al., 2013a). Both, the manager of the Rozhanovce ABP and the manager of the farm operating it agree that good-quality maize is the best substrate for biogas production. The manager of the farm continues: "the way how the EU policies were implemented law and the adjustment of agricultural payments in Slovakia are responsible for maize being used in biogas plants; we use maize in the plant because other products do not yield expected financial effects, they are not economically viable". He concludes, "The most effective symbiosis is maize and manure". Nevertheless, beside maize and manure also other substrates are utilized, i.e. sugar beet leaves (in places where sugar refineries are located) or oil-seed rape (Fáber, 2012).

Effectiveness of maize for silage with addition of liquid manure as a substrate for agricultural biogas production (as confirmed by the manager of the Rozhanovce farm) may be a reason why the acreage of maize for silage recorded increase in majority of years and regions (Fig. 3) regardless if it is a traditional crop in a given region or not. In contrary, utilization of pig manure as a substrate has not become stimulus for pig husbandry development at the nation-wide scale. It recorded decline in majority of regions and years (Fig. 4). However, the decline was the lowest in the western and northern region of Poland, where it is utilized for agricultural biogas energy production the most. This indicates that at regional scale the agricultural energy production has potential to stimulate pig husbandry positively. 
Figure 3 Development of maize for silage cultivation in Poland and Slovakia (2009-2015)

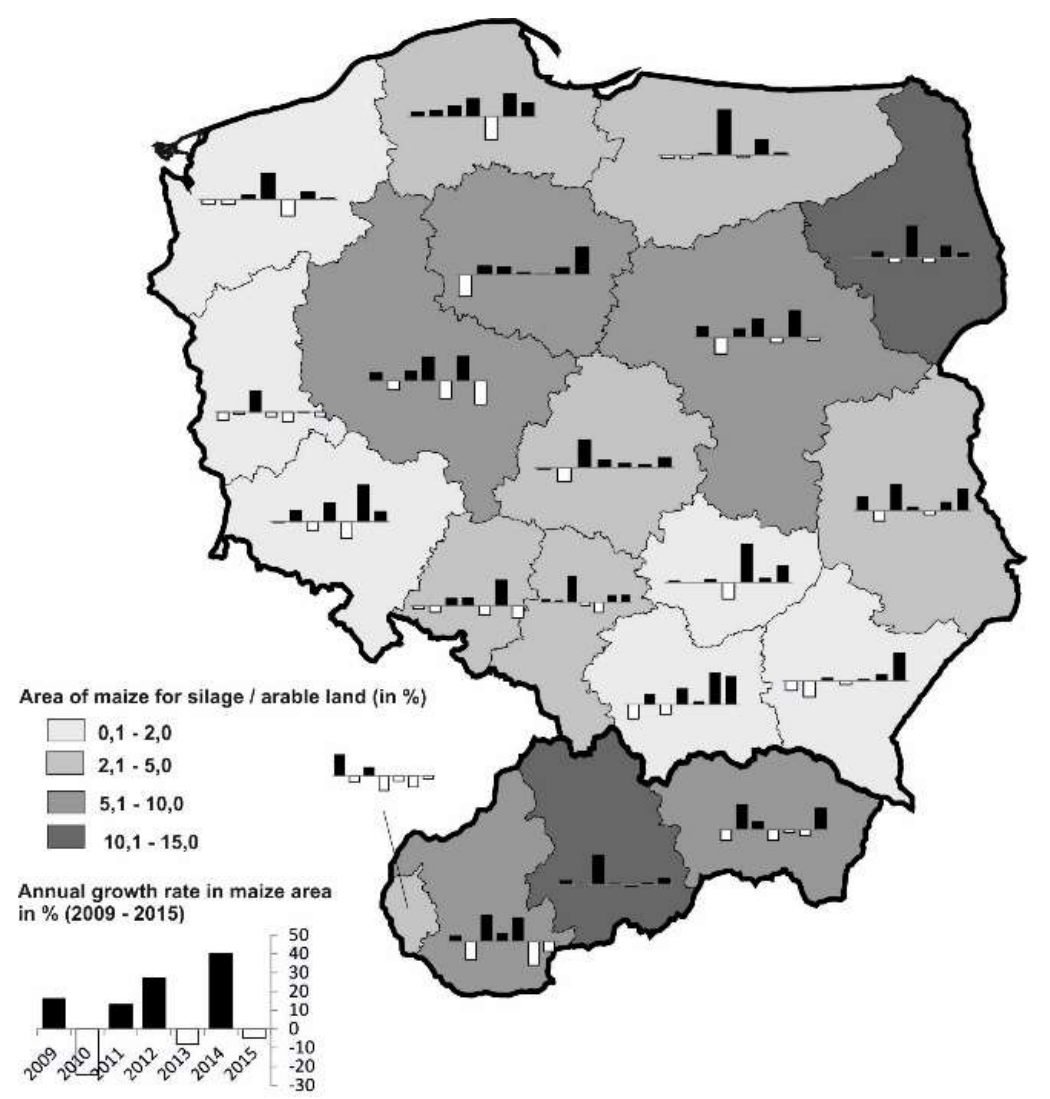

Source: LDB CSO (2015), SO SR (2008-2015)

Figure 4 Development of the pig production intensity in Poland and Slovakia (2009-2015)

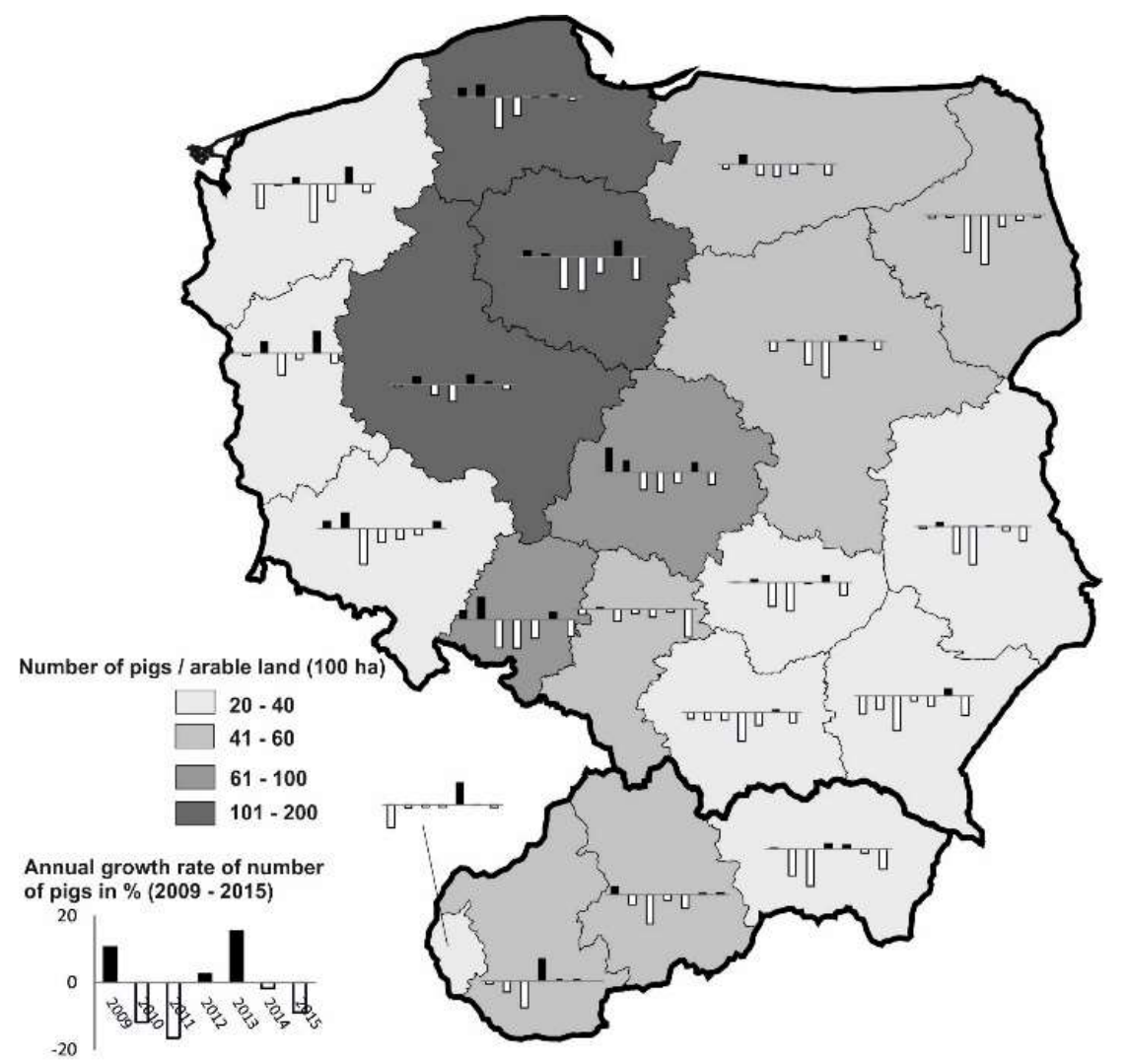

Source: LDB CSO (2015), SO SR (2008-2015) 


\section{Effects of ABPs operation to agriculture and rural development}

Differences in the forms and the ownership structure of agriculture in Poland and Slovakia allow for an analysis of the functioning of two essentially different types of ABPs: separate business entity (Buczek in Poland) and ABP run by agricultural entity itself (Rozhanovce in Slovakia). The establishment of agricultural biogas plants in Poland takes place in two different ways. On the one hand, biogas entities are being set up within the framework of already existing business organisms. Biogas investments are carried out at the stage of modernization of companies from the agri-food industry, including large-area farms after the liquidation of State Agricultural Farms. On the other hand, agricultural biogas plants are created as separate economic entities, functioning from the very beginning as independent, new enterprises in the environment of individual, relatively smaller farms and other entities with an established position in local systems. The operation of biogas plants functioning as separate economic entities leads to the growing importance of organic waste from agri-food production in the structure of substrates for the production of agricultural biogas as more easily obtainable raw materials in financial and organizational terms. However, the efficient functioning of this type of biogas plants requires deepening and broadening cooperation with local entities and becoming embedded in the local structure (Chodkowska-Miszczuk, 2019).

The ABP in Buczek, located in Kujawsko-Pomorskie region (Fig. 1), belongs to the holding company Eteron Group with headquarters in the city of Poznań. It launched operation in 2014 with total installed electric capacity 1.8 MW. Since the beginning of operation, the biogas production was based on the waste from agri-food production and silage from maize, but over the time, the proportion of these substrates changed in favor of the agri-food waste, due to changes in legislative and financial support in Poland (cf. Chodkowska-Miszczuk et al., 2017). In fact, the utilisation of this waste for biogas production became a significant source of income for the biogas enterprise. This is because ABP utilizes the waste that cannot be used in other ways (organic sediments, post-slaughter waste, etc.) and factories producing it have to pay for its disposal. It also means that legislative and financial support changes contributed to the decrease in the direct impact of the ABP's operation on agriculture on the input side, but did not affect the impact on output side, and hence the distribution and sale of organic fertilizer among local farmers.

Biogas plant in Rozhanovce is situated in the Eastern Slovakia, about $15 \mathrm{~km}$ from the city of Košice. The operation launched in 2011. The plant with the output of $1.0 \mathrm{MW}$ is run by the agricultural business entity AT ABOV s.r.o (the subsidiary corporation of AGROTRADE 
GROUP Rožňava) and operates within premises of a former socialist agricultural cooperation currently owned by AT ABOV. The silage from maize is the dominant substrate.

According to the field research conducted in Rozhanovce, installed capacity of 1.0 MW of energy requires 500 ha of maize to cover full operation. Before the biogas energy production launched, the acreage of maize in the relatively large farm was 150 ha, what constituted $8 \%$ of its total arable land. Currently, the area of maize cultivation increased more than threefold to 500 ha and the maize covers $27 \%$ of arable land. In contrast to the ABP Buczek, there is no need for green maize supplies from external subjects in the Rozhanovce ABP because the agricultural company is self-sufficient.

This confirms considerable contribution of the ABP operation to the multifunctionality of local agriculture but it raises the question of ethics of cultivating energy crops instead of these for food production. Surprisingly, even the manager of the AT ABOV perceives this issue sensitively and he confirms local population also perceives it sensitively. However, he explained that the investment to ABP based on energy crops was the only way the AT ABOV found to protect the entire farm from bankruptcy. Due to set up of financial support for agriculture in Slovakia, the production of energy crops and their further transformation into agricultural biogas energy provides enough profit to keep running whole farm with other activities that are not profitable or even lead to loss. Therefore, thanks to cultivation and processing of crops to production of agricultural bioenergy, they are able to cultivate also food crops and keep animal husbandry, keep the employment in the agriculture and so to "...keep agriculture alive, keep local people in touch with agricultural works. Because once the agricultural working habits and the relationship of community to farming are lost, it will be hardly possible to revive agriculture, and the rural areas will lose their basic function."

It shows that even without knowing or using the term multifunctional agriculture, the manager of AT ABOV see this concept as a chance to keep agriculture viable and contribute to rural economy. AT ABOV did not need to hire new employees for ABP operation, they took advantage of the original labor force that went through courses and trainings to qualify for work in the ABP. Therefore, the ABP itself directly did not increase the employment, but indirectly helped to prevent bulk redundancies. The Eteron Group had to hire new employees to launch and operate the ABP in Buczek. Because of the reoriented structure of substrates for agricultural biogas production in Buczek in favor of the agri-food waste, the number of employees doubled (during the first stage of functioning of this biogas plant the number of employees was about 4 people), which is not negligible in rural communities. Both ABPs are employing local people as well as people from surrounding cities and towns, and so through the multifunctional 
agriculture they contribute to rural economic development. The supply of new jobs in rural areas can be considered both quantitatively and qualitatively. The quality aspect is extremely important, because every new job has a positive impact on the quality of life of the inhabitants, contributes to improving the self-esteem of the local community and social cohesion (Chodkowska-Miszczuk et al., 2019).

Regarding the sustainability of $\mathrm{ABP}$ as a contribution to rural development and multifunctional agriculture, the interviews confirmed the advantage of predictability of energy production from biogas (cf. Bluemling, Mol and Tu, 2013). In this context, the manager of AT ABOV operating the ABP plant in Rozhanovce emphasizes: "The biogas plant helps us to plan. It is predictable." The Buczek ABP manager appreciates also that ,the biogas plant is the most efficient of all RES installations, close to 100\%" which results from the predictability and almost $100 \%$ utilization of substrates and by-products.

The hourly average output is $1.6 \mathrm{MW}$ from the ABP Buczek and 1.0 MW from the ABP in Rozhanovce. Electricity generated by both examined ABPs is fed into the national electricity distribution networks. Therefore, the main output of ABPs is not directly beneficial for the rural development, but there is a great potential to utilize the heat this way. However, this is still at the design stage in majority of ABPs in post-socialist CECs, due to infrastructural and administrative barriers. Therefore, the thermal energy produced in majority of ABPs is used only for heating of own premises or smaller industrial or storages properties adjacent to ABPs, rarely also greenhouse complexes such as in Kameničany in Western Slovakia (NWT 2018). Despite certain projects and existing interest from ABPs operators as well as local institutions and organizations in Buczek and Rozhanovce, infrastructural and administrative constraints hinder distribution of heat to external consumers. The local community also perceives that the use of heat from the ABPs can be beneficial. A local leader from Buczek mentions that "[the biogas plant] could be placed a little closer to the blocks [offlats] in order to use the heat." In addition, the representative of the Rozhanovce municipal office states: "Heat can be used at any moment. We have an idea to heat the school, for example, but who will finance the infrastructure? We are ready to grab a chance if there will be appropriate call for the projects funded by EU."

Also the local community sees the opportunity to use ecological, cheap and locally generated heat and so to participate not only in the costs of functioning of biogas plants located in their area, but also in their profits. This is best reflected in the stance of the representative of the Rozhanovce municipal office: "If this idea connected with heat distribution was implemented, 
then we would have an argument for community: we tolerate the stench because we have cheap heat."

Another asset of ABPs for rural areas and local farmers is in the possibility of acquiring a digestate, a biogas by-product, which is relatively cheap, environmentally friendly, and efficient organic fertilizer (Kowalczyk-Juśko, 2011, Auer et al., 2017). The digestate is successfully utilized by the farm in Rozhanovce with the same owner as the ABP. The ABP in Buczek cannot utilize the digestate itself because its operator does not own any agricultural land, but based on agreement by the Ministry of Agriculture and Rural Development in Poland (MARD), it distributes the digestate to the local farmers. One of the local leader concludes: „It [ABP plant] most certainly cooperates (...) with the local farmers, surely, because the digestate is transported to the fields as fertilizer and I think the farmers take it gladly. Because I can see they are taking it". According to the residents, this distribution had a negative impact on their quality of life. There was an increase in road traffic, odor discomfort and other effects. "The removal of the digestate causes inconvenience and this is kind of the main problem I see with the construction and exploitation of such installations". Therefore, the production and utilization of digestate is another possible to ABPs' contribution to multifunctional agriculture and subsequently the rural development, albeit perceived ambiguously by local community. In the case of the biogas plant in Buczek, the fertilizer is becoming more and more well-known and valued by local farmers. The biogas plant makes the product available free of charge and ensures its transport (within a radius of up to $15 \mathrm{~km}$ from the biogas plant). Transport costs are the only charges paid by farmers.

Biogas plants operating in a given area, as innovative energy enterprises, initiate a number of actions aimed at becoming integrated into local socio-economic structures. Even if the biogas plant is integrally connected with an existing agricultural enterprise (farm), it endeavors to expand the range of entities with which it cooperates in the supply chain. Biogas entrepreneurs look for new partners, especially at the local level. Due to the convergence of industries, important cooperation is carried out with farmers - suppliers of substrates and recipients of organic fertilizer.

\section{The significance of biogas plants in the opinion of rural inhabitants}

Both analyzed biogas plants play significant role in local economy, and are recognized by the local communities. The question: "Do you know the biogas plant?" was referred to by almost 75\% of respondents: "Yes, I have heard of it". The recognizing is higher among middle-aged inhabitants, while proportion of positive responses is lower among younger people and 
pensioners. Especially in suburban municipality of Rozhanovce, the proportion of these who know about the local ABP is low among newcomers who reside in municipality less than five years. It can mean that they just did not recognized it because it already operated before their arrival, and also many of them as suburbanizers reside the municipality but are not tied with it. They do not pay attention to local affairs because they do majority of activities in the nearby city and come to municipality only to stay overnight. For both localities also applies that the higher educational attainment the larger proportion of those who recognize the operation of $\mathrm{ABP}$ in local community. However, there are no statistically significant differences among categories by age, gender or education regarding positive or negative perception of the ABPs' operation. Majority of inhabitants are aware of the fact that biogas plants cooperate with local entities, both from private sphere (farmers, services) as well as the public one (local authorities), however, the proportion of these who do not have enough information is also the largest among the newcomers. The example of such a cooperation activity with the local community are meetings organized by the manager of the biogas plant in Buczek regarding the possibility of purchasing fertilizer, its quality, but also active participation in local events significant for a particular local community. As far as a biogas plant operating within an agricultural enterprise is concerned, numerous responses appeared that prove the lack of knowledge referring to ABP: I have no idea, I don 't know anything, etc.

Taking into consideration opinions of inhabitants on the significance of ABPs in the local economy one ought to pay attention to the structure of the response to the issue: "What do you think about the biogas plant?" When it comes to a biogas plant operating as a separate subject the most responses were for the option: "It is good it is here, it provides jobs". The following one was the opinion on the role of a biogas plant in the promotion of the village. The third in the order by number of respondents was negative opinion referring to the unpleasant smell and unattractive look of the biogas plant. However, negative opinion dominated in Rozhanovce, where a biogas plant operates within an agriculture enterprise. The most frequent responses were "It smells and looks ugly" or "Only the owners benefit from it". The opinion claiming that: "It is good it is there, it provides jobs" was on the third position. In both analyzed cases, negative perception is mainly associated with the distribution and soil application of organic fertilizer as well as excessive traffic near the biogas plant (Fig. 5). 
Figure 5 The distribution of the answer to the question: „What do you think about the ABP?”
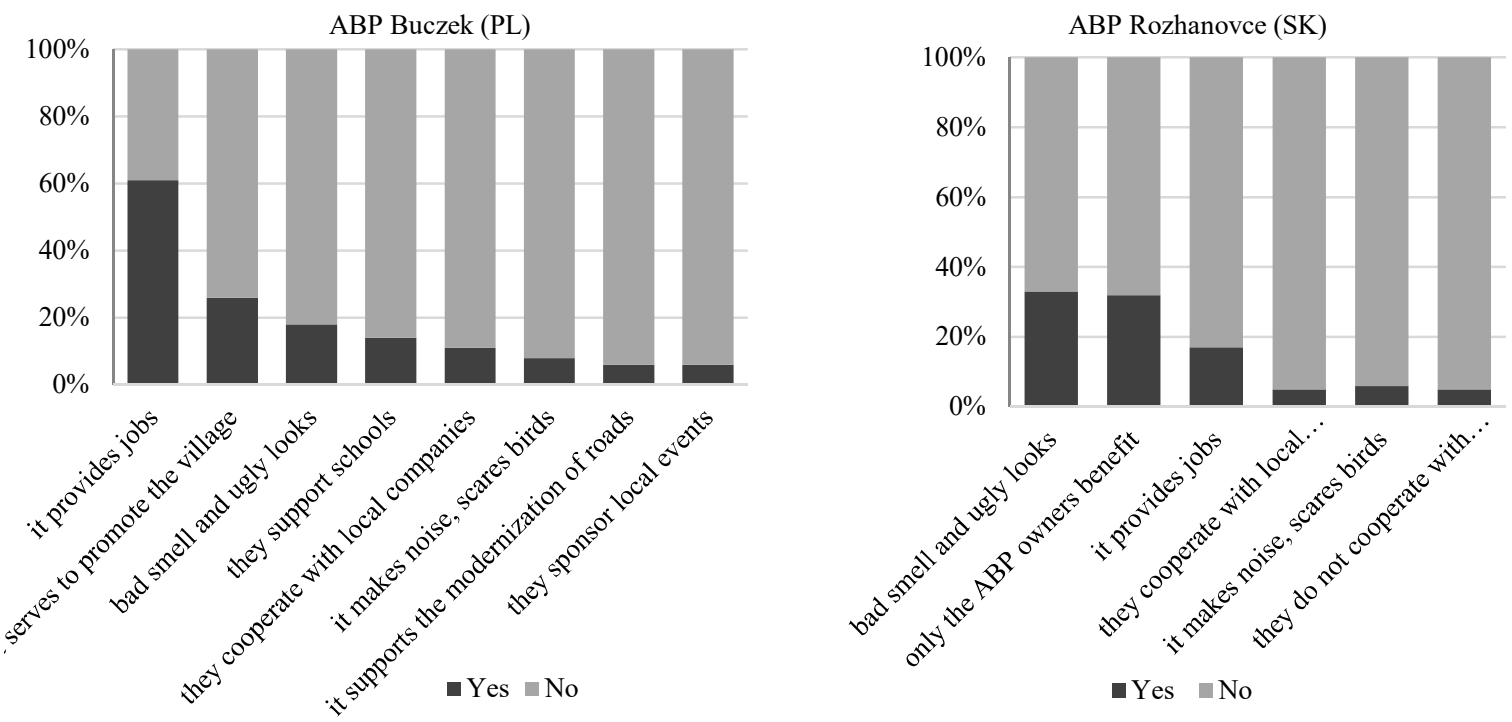

Source: own study based on the survey results $(\mathrm{N}=150)$

Taking into account the further efficient coexistence of the ABPs in the local environment one ought to undertake certain activities aiming at strengthening the links with local communities. As the respondents point out: "What is the most important is the fact that inhabitants should be informed about activities taken". The inhabitants are willing to get to know the rules of how a biogas plant operates, as well as the results of its functioning (both advantages and disadvantages). It is also important to make it possible for inhabitants to participate in profits of the enterprise, not only bear the expenses of its existence. Thus, there are numerous demands of the respondents on the issue of taking advantage of (cheaper) energy, including the heat created by biogas plants, as well as the necessity of participation on the side of biogas plants owners in modernization of local technical facilities exploited in economic activities.

\section{CONCLUSIONS}

The research results presented in this paper pointed at the agricultural biogas plants (ABPs) in Poland and Slovakia as a new phenomenon affecting the agriculture and rural development in post-socialist Central European countries (CECs) in various aspects. The focus of the EU countries to increase proportion of energy generated from RES stimulated rapid development of biogas energy production in the CECs. Despite simultaneous development of technologies, agricultural biogas energy production still depends on the state support, as it is more expensive than conventional energy production, and so its development is determined by the national legal and financial support. However, the research shows that ABPs operation contributes to the development of multifunctional agriculture and provides stimuli for rural economic 
development, what is often an overlooked aspect of return of the state support back to the national budgets.

Mutual conditionality was confirmed between operating ABPs and regional agricultural structures. Intensity of agricultural production is among the factors determining location of APB the most. In the same time, ABPs operation considerably affects the use of arable land. Since the agricultural biogas energy production experienced rapid growth, areas of maize cultivation for energy production grew significantly at the expense of crops for food production. This applies particularly in the regions where the large farms dominate in agricultural spatial structure as a consequence of collectivization under socialism.

The growth of areas of maize for silage cultivation raises concerns about too excessive focus of agriculture on non-nutrition monocultures and it is perceived as moral and ecological danger. This can be a challenge for state legislations, following the example of Germany, to support more the construction of small ABPs (up to $500 \mathrm{~kW}$ ), which would predominantly process naturally produced agricultural waste. However, the recent development in Poland illustrated by the case of the Buczek plant shows that a well-designed support system can motivate ABPs operators so increase proportion of agri-food waste in the structure of input substrates at the expense of energy crops even without changing the ABPs' size structure.

Spatial structure of agriculture affects also character of ABPs as business entities. Average size of a farm in Poland is among the smallest and in Slovakia among the largest in the EU. This allows large Slovak agricultural companies to run ABPs within their premises, acquiring biogas from substrates produced by the companies themselves as well as utilizing digestate the biogas by-product as a very efficient and environmentally friendly organic fertilizer directly at their own arable land. This is only rarely possible in Poland, where small farms dominate. Majority of ABPs operates as a separate (non-agricultural) business entity forced to establish relationships with agricultural suppliers and buyers of the by-products. Agriculture in Poland has underwent post-socialist transformation relatively successfully, but many agricultural companies in Slovakia bankrupted after privatization and many other still fight for survival. Thus, biogas energy production is perceived as a suitable way to diversify business activities within agricultural companies and thanks to development of multifunctional agriculture to stabilize their operation and financial situation.

These facts directly underline the significance of ABPs not only as a factor influencing the changes in agriculture but also as an important element of rural development generally. Along with a positive impact on a more even distribution of energy sources, ABPs directly provide 
new job opportunities, or at least help to maintain existing jobs in rural areas. This is very important local development stimulus, since during the post-socialist transformation, employment in agriculture was reduced considerably and rural areas generally suffer from a shortage of jobs.

Possible resentment among the local population arising from new element in rural area can be overcome by sponsorship of local institutions, civic associations and various social and cultural events. All this happens in both kinds of ABPs, but to a much less extent in ABP as integral part of a large agricultural company. Nevertheless, both kinds of ABPs also have untapped potential to support the development of the rural areas. Energy produced is distributed into national distribution networks but heat produced in cogeneration is only used for own premises. Infrastructural and administrative constraints hinder distribution of heat to external consumers, although it could be cheaper and more ecological heating than currently used conventional heating options.

ABPs are a relatively new phenomenon in CECs. Much more research will be needed to understand their role and impact on national economies, redistribution of energy production, environmental impact and other aspects of their operation. This paper provides important evidence and fills the gap in the knowledge on the impact of ABPs operation on multifunctional agriculture and rural development, which are aspects very often overlooked in the related research.

\section{Acknowledgments}

We would like to express our gratitude to the all respondents of our survey for providing information and opinions, and supporting data and materials necessary for this research. This work was supported by the National Science Centre, Poland, Project no. 2016/21/D/HS4/00714: Biogas enterprises from the perspective of the embeddedness concept and Slovak Research Grant Agency (VEGA) under the grant 1/0395/17: Centripetal and centrifugal processes in transformation of regional system in Slovakia.

\section{REFERENCES}

Ackermann, T., Andersson, G., \& Söder, G. L. (2011). Distributed generation: a definition. Electric Power Systems Research, 57, 195-204.

Act No. 309/2009 Coll., 2009. The Act No. 309 of 19 June 2009 on the Promotion of Renewable Energy Sources and High-Efficiency Cogeneration. Bratislava: National Council of Slovak Republic. [in Slovak]

Act No. 478/2015 Coll., 2015. The Act No. 478 of 20 February 2015 on Renewable Energy Sources. Warsaw: Official Journal of Laws of the Republic of Poland 2015. [in Polish] AMA (Agricultural Market Agency in Poland). (2016). Register of agricultural biogas generators 2016. Retrieved from http://www.arr.gov.pl/wytworcy-biogazu-rolniczego/rejestr- 
przedsiebiorstw-energetycznych-zajmujacych-sie-wytwarzaniem-biogazu-rolniczego). [accessed 10 May 2016]. [in Polish]

Anderson, J., Håkansson, H., \& Johanson, J. (1994). Dyadic business relationships within a business network context. Journal of Marketing, 58, 1-15.

Auer, A., Vande Burgt, N.H., Abram, F., .Barry, G., Fenton, O., Markey, B.K., ...Zintl, A. (2017). Agricultural anaerobic digestion power plants in Ireland and Germany: policy and practice. Journal of the Science of Food and Agriculture, 97(3), 719-723.

Bański, J. (2008). Agriculture of Central Europe in the period of economic transformation, Contemporary changes of agriculture in East-Central Europe. Rural Studies, 15, 7-20.

Bluemling, B., Mol, A. P. J., \& Tu, Q. (2013). The social organization of agricultural biogas production and use. Energy Policy, 63, 10-17.

Boehmel, C., Lewandowski, I., \& Claupein, W. (2008). Comparing annual and perennial energy cropping systems with different management intensities. Agricultural Systems, 96, 224236.

Bożym, M., Florczak, I., Zdanowska, P., Wojdalski, J., \& Klimkiewicz, M. (2015). An analysis of metal concentrations in food wastes for biogas production. Renewable Energy, 77, 467472.

Budzianowski, W. M. (2012). Sustainable biogas energy in Poland: Prospects and challenges. Renewable and Sustainable Energy Reviews, 16, 342-349.

Budzianowski, W. M., \& Chasiak, I. (2011). The expansion of biogas fuelled power plants in Germany during the 2001-2010 decade: Main sustainable conclusions for Poland. Journal of Power Technologies, 91, 102-113.

Buzar, S. (2007). Energy Poverty in Eastern Europe. Hidden Geographies of Deprivation. Ashgate Publishing Company, Burlington.

Carrosio, G. (2014). Energy production from biogas in the Italian countryside: Modernization vs. repeasantization. Biomass and bioenergy, 70, 141-148.

Chodkowska-Miszczuk, J. (2014). Small-Scale Renewable Energy Systems in the Development of Distributed Generation in Poland. Moravian Geographical Reports, Special Issues: New Trends and Challenges for Energy Geographies, 22, 34-43.

Chodkowska-Miszczuk, J. (2019). Biogas enterprises in local development in the context of embeddedness concept, Nicolaus Copernicus University in Toruń. [in Polish]

Chodkowska-Miszczuk, J., \& Szymańska, D. (2013). Agricultural biogas plants - A Chance for diversification of agriculture in Poland, Renewable and Sustainable Energy Reviews, 20, 514-518.

Chodkowska-Miszczuk, J., Biegańska, J., Środa-Murawska, S., Grzelak-Kostulska, E., \& Rogatka, K. (2016). European Union funds in the development of renewable energy sources in Poland in the context of the cohesion policy. Energy \& Environment (Brentwood), 27, 713-725.

Chodkowska-Miszczuk, J., Kulla, M., \& Novotný, L. (2017). The role of energy policy in agricultural biogas energy production in Visegrad countries. Bulletin of Geography. Socio-economic Series, 35, 19-34.

Chodkowska-Miszczuk, J., Martinat, S., \& Cowell, R. (2019). Community tensions, participation, and local development: Factors affecting the spatial embeddedness of anaerobic digestion in Poland and the Czech Republic. Energy Research \& Social Science $55,134-155$.

Converse, A. O. (2007). Renewable energy in the United States: Is there enough land? Applied Biochemistry and Biotechnology, 137-140, 611-624.

Curkowski, A. (2012). Agricultural biogas market. Current state and prospects for the development of the sector. Heat and Power Engineering, 12/2011-1/2012, 1-6. [in Polish] 
deLlano-Paz, F., Calvo-Silvosa, A., Iglesias Antelo, S., \& Soares, I. (2015). The European lowcarbon mix for 2030: The role of renewable energy sources in an environmentally and socially efficient approach. Renewable and Sustainable Energy Reviews, 48, 49-61.

Directive 2009/28/EC of the European Parliament and of the Council of 23 April 2009 on the promotion of the use of energy from renewable sources. (http://eur-lex.europa.eu/legalcontent/EN/TXT/?uri=celex:32009L0028). [accessed 06 October 2016].

Eurostat, 2008-2014. Areas harvested, yields, production by NUTS 2 regions (data for 20082014).(http://appsso.eurostat.ec.europa.eu/nui/show.do?dataset=agr_r_landuse\&lang=). [accessed 12 September 2015].

Fáber, A. ed. (2012). Atlas of renewable energy sources use in Slovakia. Energy centre Bratislava. Bratislava. [in Slovak]

Fischer, T., \& Krieg, A., (2001). Agricultural biogas plants - worldwide. International Congress, Renewable Energy Sources in the Verge of XXI Century, Warsaw Retrieved from http://www.kriegfischer.de/public.html)

Gaduš, J., \& Giertl, T. (2010). Biogas from agricultural biomass - Effective energy carrier. Agrobioenergia, 4, 4-5. [in Slovak]

Granovetter, M. (1985). On the Embeddedness of Social Life. American Journal of Sociology, 91, 481-493.

Han, J., Mol, A. P. J., Lu, Y., \& Zhang, L. (2008). Small-scale bioenergy projects in rural China: Lessons to be learnt. Energy Policy, 36, 2154-2162.

Jean-Vasile, A. (2013). Multifunctional agriculture and the green economy. In Jean-Vasile, A. et al. eds. Sustainable Technologies, Policies, and Constraints in the Green Economy. Hershey, PA (IGI Global), 290-311. Doi:10.4018/978-1-4666-4098-6.ch016

Kats, G. H. (1991). Energy options for Hungary a model for Eastern Europe. Energy Policy, $19,855-868$.

Khanna, M., Louviere, J., \& Yang, X. (2017). Motivations to grow energy crops: the role of crop and contract attributes. Agricultural Economics, 48(3), 263-277.

Kowalczyk-Juśko, A. (2011). Fertilizer use of fermentation residues on the example of the researches carried by Institute of Soil Science and Plant Cultivation in the agricultural biogas plants. Dębowa Kłoda and Poldanor 2011. Retrieved from https://www.minrol.gov.pl/pol/content/download/40149/222513/file/A.Kowalczyk-Jusko\% 20-\%20Nawozowe\%20wykorzystanie\%20pozostalosci\%20pofermentacyjnych.pdf. [accessed 06 October 2016]. [in Polish]

Kulišić, B., Par, V., \& Metzler, R. (2015). Calculation of on-farm biogas potential: A Croatian case study. Biomass and bioenergy, 74, 66-78.

Lantz, M., Svensson, M., Björnsson, L., \& Börjesson, P. (2007). The prospects for an expansion of biogas systems in Sweden Incentives, barriers and potentials. Energy Policy, 35, 18301843.

LDB CSO (The Local Data Bank from the Central Statistical Office in Poland), 2015. Rolnictwo, łowiectwo, leśnictwo. Central Statistical office in Poland 2015. Warszaw. (http://stat.gov.pl/bdl/app/dane_podgrup.hier?p_id=110872\&p_token=314428980). [accessed 07 December 2015]. [in Polish]

Lunnan, A. (1997). Agriculture - based biomass energy supply - a survey of economics issues. Energy Policy, 25, 573-582.

Martinát, S., Dvořák, P., Klusáček, P., Kulla, M., \& Mintálová, T. (2013). Importance of agricultural anaerobic digestion plants for agriculture and rural development: notes on researches carried out in the Czech Republic and Slovakia. Rural Development, 6, 168-176.

Martinát, S., Dvořák, P., Frantál, B., Klusáček, P., Kunc, J., Kulla, M., ...van der Horst, D., (2013). Spatial Consequences of Biogas Production and Agricultural Changes in the 
Czech Republic after EU Accession: Mutual Symbiosis, Coexistence or Parasitism? Acta Universitatis Palackianae Olomucensis. Geographica, 44, 1-18.

Masár, I., Božík, M. (2009). Analysis of Renewable Energy and its Impact on Rural Development in Slovak Republic. AgriPolicy Enlargement Network for Agripolicy Analysis. Retrieved from www.euroqualityfiles.net/AgriPolicy/Report 2.2/AgriPolicy WP2D2 Slovakia Final.pdf. [accessed 06 October 2017]. [in Slovak]

Miles, M.B., \& Huberman, M.A. (1994). Qualitative Data Analysis: An Expanded Sourcebook. Second Edition, Sage Publications, London, New Delhi.

NAP for RES: National Action Plan for RES (2010). Ministry of Economy of the Slovak Republic, Bratislava. Retrieved from http://www.economy.gov.sk/narodny-akcny-planpre-energiu-z-obnovitelnych-zdrojov/135436s). [10 October 2016]. [in Slovak]

National Centre for Agriculture Support (NCAS) Retrieved from http://www.kowr.gov.pl/ [accessed 10 June 2018]. [in Polish]

Némethová, J. (2010). Vybrané faktory multifunkčného pol'nohospodárstva v Nitrianskom kraji. Geographia Cassoviensis 4(2), 131-136.

Nonhebel, S. (2007). Energy from agricultural residues and consequences for land requirements for food production. Agricultural Systems, 94, 586-592.

NWT (2018). How we grow. We protect nature. The website of the Kameničany farm. (http://farmakamenicany.eu/how-we-grow/). [accessed 03 August 2018].

Obłój, K. (2000). Business success strategy. Polish Economic Publishing House, Warsaw. [in Polish]

Ostrowska, A. (2012). Legal-administrative barriers for the construction of agricultural biogas plants in Poland. Acta Universitatis Lodziensis, Folia Oeconomica, 270, 127-135. [in Polish]

Raven, R. P. J. M., \& Geels, F. W. (2010). Socio-cognitive evolution in niche development: Comparative analysis of biogas development in Denmark and the Netherlands (19732004). Technovation, 30, 87-99.

Reise, C., Musshoff, O., Granoszewski, K., \& Spiller, A. (2012). Which factors influence the expansion of bioenergy? An empirical study of the investment behaviours of German farmers. Ecological Economics, 73, 133-141.

Renting, H., Rossing, W.A.H., Groot, J.C.J., Van der Ploeg, J.D.,Laurent, C., Perraud, D., , ...Van Ittersum, M.K. (2009). Exploring multifunctional agriculture. A review of conceptual approaches and prospects for an integrative transitional framework. Journal of environmental management, 90(2), 112-123.

RONI (Regulatory office for network industries), 2014. Comparison of RES support and redemption prices of electricity produced from RES in neighbouring countries. Bratislava Retrived from http://www.urso.gov.sk/sites/default/files/Vykupne-ceny-OZE-v-EU2014 .pdf. [accessed 06 June 2015]. [in Slovak]

RONI (Regulatory office for network industries), 2017. RONI (Regulatory office for network industries), 2017. List of energy producers with support for 2017. Bratislava. Retrieved from http://www.urso.gov.sk/sites/default/files/dokumenty/OZE_Zoznam-Vyrobcov-sdoplatkom -za-rok-2017 v2.pdf). [accessed 9 July 2019]. [in Slovak]

Rusňák, P., Pepich, Š., \& Muráňová, K. (2013). Present and perspectives of agricultural biogas plants in Slovakia. Slovgas, 22, 10-13. [in Slovak]

Schulz, H., \& Eder, B. (2004). Biogas in practice. HEL Ostrava, 2004.

Silva, S., Alçada-Almeida, L., \& Dias, L. C. (2014). Biogas plants site selection integrating Multicriteria Decision Aid methods and GIS techniques: A case study in a Portuguese region. Biomass and bioenergy, 71, 58-68.

Sims, H. R., Hastings, A., Schlamadinger, B., Taylor, G., \& Smith, P. (2006). Energy crops: current status and future prospects. Global Change Biology, 12, 2054-2076. 
SOSR (Statistical Office of the Slovak Republic), 2008-2015. List of areas with cultivation of agricultural crops for 2008-2015. Bratislava. [in Slovak]

SOSR (Statistical Office of the Slovak Republic), 2008-2017. Yearbook: Energy. Bratislava.

Swinnen, J., \& Weersink, A. (2013). Challenges and policy options in the global bio-economy: introduction and overview. Agricultural Economics, 44(4-5), 379-380.

Szymańska, D., \& Lewandowska, A. (2015). Biogas power plants in Poland: structure, capacity, and spatial distribution. Sustainability, 7, 12, 16801-16819.

Van der Horst, D., Martinát, S., Navrátil, J., Dvořák, P., \& Chmielová, P. (2018). What can the location of biogas plants tell us about agricultural change? A case study from the Czech Republic. Deturope, 10, 1, 33-52.

Van Ploeg J.D., Ranking H., Brunori, G., Knickel, K., Mannion J., Marsden T., ...Ventura F. (2000). Rural development: From practices and policies towards theory. Sociologia Ruralis, 40, 391-408.

Weiland, P. (2003). Production and Energetic Use of Biogas from Energy Crops and Wastes in Germany. Applied Biochemistry and Biotechnology, 109, 263-274.

Wilson, G.A. (2007). Multifunctional Agriculture. A transition theory and perspective. Cromwell Press. 318 p.

Wirth, S., Markard, J., Truffer, B., \& Rohracher, H. (2013). Informal institutions matter: Professional culture and the development of biogas technology. Environmental Innovation and Societal Transitions, 8, 20-41.

Wolfe, P. (2008). The implications of an increasingly decentralised energy system. Energy Policy, 26, 4509-4513.

Yabe, N. (2013). Environmental and economic evaluations of centralized biogas plants running on cow manure in Hokkaido, Japan. Biomass and Bioenergy, 49, 143-151.

Yang, J., \& Chen, B. (2014). Energy analysis of a biogas-linked agricultural system in rural China - A case study in Gongcheng Yao Autonomous County. Applied Energy, 118, 173182. 